\title{
Correspondence
}

\section{Taxonomic glory easier on eBay?}

One of zoology's highest honours may now, it seems, be purchased on eBay (see go.nature.com/ ziq152). For a few thousand dollars, you are offered the privilege of naming a 'small, rare' species. A species name will last forever, says the vendor - even as taxonomists themselves struggle to survive.

Taxonomists invest months confirming that a specimen is new to science. They sift through obscure literature -

often in a different language and lamentably illustrated. More months are spent on the species' description, which must be accurate enough to enable future taxonomists (should they survive the sixth mass extinction) to confirm that their 'new' species is different. Eventually, they publish their work in a systematics journal with an impact factor typically below 2 - even when the species is a previously undescribed mammal (the olinguito Bassaricyon neblina, pictured; see K. M. Helgen et al. ZooKeys 324, 1-83; 2013).

These low impact factors make it hard for taxonomists to land positions in academia, and job opportunities in museums are sparse. Selling perpetuity on eBay is starting to look like an attractive alternative.

Giovanni Strona European Commission, Joint Research Centre, Institute for Environment and Sustainability, Ispra, Italy. giovanni.strona@jrc.ec.europa.eu

\section{Europe needs Ebola outbreak consortium}

The European Commission (EC) has been criticized for failing to define specific research pathways for tackling the recent outbreak of Ebola virus in West Africa (J. M. Martin-Moreno et al. Lancet 384, $1259 ; 2014)$. In our view, three changes would improve research into new interventions.

First, the EC needs to set up

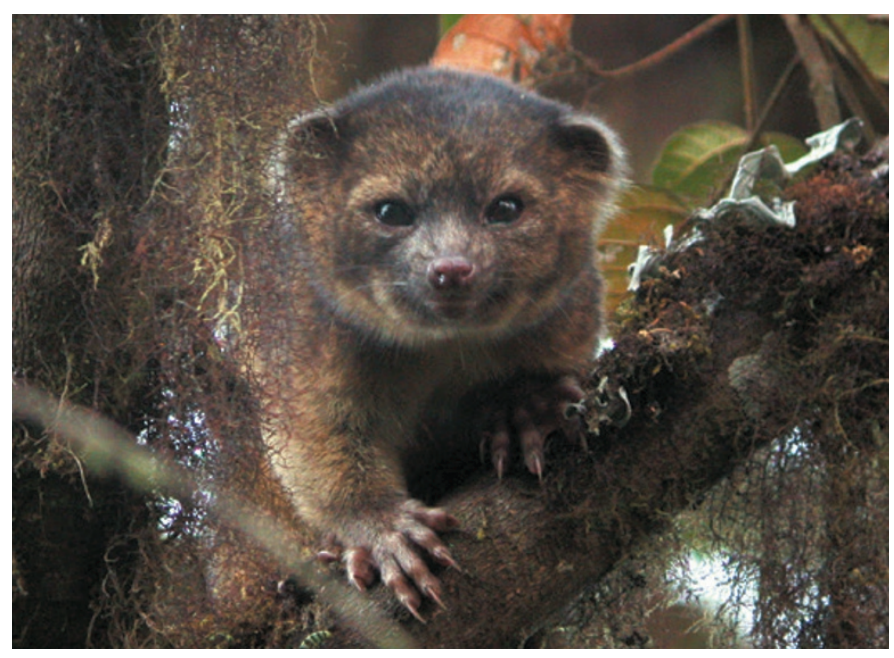

a cooperative framework for implementing research activity during outbreaks. Experience indicates that existing networks have suboptimal capability to involve African institutions and local authorities in the research that could help to contain the epidemic (S. Lanini et al. Lancet Infect. Dis. 15, 738-745; 2015).

Second, the EC must put in place resources and infrastructure so that, in the event of an unexpected resurgence of the virus, intervention studies can be rapidly approved.

Third, research institutions need to cooperate more closely with one another. Research networks have already been set up (see go.nature.com/9xtemn) and others have successfully supported fragile local healthcare services. These include the European Mobile Laboratory Project, Quality Assurance Exercises and Networking on the Detection of Highly Infectious Pathogens, and the network of biosafety level 4 laboratories, Euronet P4.

We suggest that an inclusive and committed European Consortium should be established. This should carry out research between epidemics and promptly translate the results into actions during epidemics. In our view, this consortium would be most effective if it were self-sufficient. Crucially, its budget structure would allow easy access to funds for implementing interventions. Alimuddin Zumla University College London, London, UK. David Heymann Chatham House Centre on Global Health Security, London, UK.

Giuseppe Ippolito National institute for Infectious Diseases, Rome, Italy. giuseppe.ippolito@inmi.it

\section{Animal studies must be useful, says public}

The European Commission

(EC) responded last month to 'Stop Vivisection', a European Citizens' Initiative to phase out animal testing, which was signed by more than one million people. The EC confirmed that it will not replace the existing directive on the protection of animals used for scientific purposes (2010/63/EU), which already matches the level of protection in countries with the most demanding legislation. Yet the citizens' principal argument relates not to animal suffering, but to the limited usefulness of results from animal models.

Citizens concerned about animal welfare may still accept research that is perceived as being of ultimate benefit to humans, but only if it delivers relevant results - a view that evidently helped to mobilize signatures in this case. This is one of only three citizens' initiatives since 2012 that have gathered enough signatures to reach the EC, so the scientific community needs to take its criticisms seriously.

As long as blinding, randomization and appropriate sample sizes are not standard practices in animal research, claims of maximizing its benefits are not credible. Unreliable data from poorly designed studies and publication bias give misleading results on the therapeutic value of candidate drugs, leading to disappointing clinical trials (see, for example, S. Perrin Nature 507, 423-425; 2014). Researchers must aim to do research that stands up to critical scrutiny from all quarters.

I. Anna S. Olsson, Nuno H. Franco Institute for Molecular and Cell Biology, Porto, Portugal. olsson@ibmc.up.pt

\section{A prescient view of women in evolution}

The remarkable nineteenthcentury German biologist August Weismann (Nature 522, 31-32; 2015) also took a prescient stand in the discourse on the role of women in evolution.

Weismann challenged a popular theory of heredity proposed by US zoologist William K. Brooks in The Law of Heredity (Murphy, 1883). On the basis of the Lamarckian idea of an inheritance of acquired characteristics, Brooks argued that the 'hereditary force', or Vererbungskraft (Weismann's translation), was stronger in men than in women, writing that "something within the animal compels the male to lead and the female to follow in the evolution of new breeds". Weismann roundly refuted this idea, pointing out that children inherit as many characteristics from their mothers as from their fathers (A. Weismann Die Bedeutung der Sexuellen Fortpflanzung für die Selections-Theorie; Fischer, 1886). U. Kutschera Institute of Biology, University of Kassel, Germany. kut@uni-kassel.de 